\title{
MANAGING KNOWLEDGE: SOCIAL ORGANIZATIONS IN THE UK AND POLAND
}

This paper reports the findings from an extensive study of small social organizations. The study included 10 groups from England and Poland. 31 individuals, representing a mixture of locally operating social enterprises and organizations, were interviewed and the transcripts analyzed using Interpretative Phenomenological Analysis (IPA). Altruistic and other forms of motivation, situated learning and other forms of knowledge management and transfer were investigated.

The research hypothesis was that qualitative analysis techniques could reveal the motivation to form, join, participate in, and lead these communities of practice (CoPs), and evaluate the knowledge transfer techniques occurring.

The aim was to probe and evaluate these processes qualitatively, using IPA techniques on CoPs operating with widely differing technical purposes, in differing cultures. The results demonstrate that situated learning and knowledge management were clearly apparent. Knowledge transfer was evident, and a transition from legitimate peripheral participation to mature leadership was often seen. This was especially evident for management skills, and their operationalization in these organizations.

There are many similarities between the Polish and UK organizations, despite clear cultural differences. The country of operation, and the "technical" purposes of the organizations, although very different, did not greatly influence the mechanisms of knowledge management or transfer reported.

Keywords: management, knowledge, social organizations.

\section{INTRODUCTION}

This paper reports the findings from an extensive study of people working in communities of practice, who create and run small social organizations. The study looked at 10 groups in Northern England and Southern Poland, specifically by interviewing the people in them, who act voluntarily for the good of others. Their motivations, their chosen processes, and their group achievements were studied and assessed. The chosen focus was restricted to people and their interactions, specifically forms of knowledge transfer, when they work together in a CoP for a social purpose. The authors believe that this type of study is under-researched and so have been considering it for a number of years.

"Organizations" and "enterprises" are labels that can be used to describe groups of individuals, working in many ways, and using widely different processes, but always with one or more common goals. The labels have subtly different meanings in different cultures, so their use here needs definition. Simply, enterprise has monetary connotations,

\footnotetext{
${ }^{1}$ Zbigniew Zontek, Ph.D., Faculty of Management and Transport, University of Bielsko-Biala, corresponding author, e-mail: zzontek.ath@gmail.com

${ }^{2}$ Christopher Whitworth, Assistant Professor, retired, Leeds Metropolitan University.
} 
in this context mainly fund-raising, whilst organization applies when money is very much a secondary consideration to a specific, technical purpose. The selected cases here consider both types of CoP. Due to the limited space, none of the cases are reported in depth, however a book is to be published which will enlarge on the detail.

Thus, in some cases, the $\mathrm{CoP}$ focus is on social enterprise, learning about and operationalizing fund-raising via some form of business "enterprise", to raise money for their social good. The study of the Yorkshire Air Ambulance charity in the UK, and a fund-raising motorcyclists group in Poland exemplify this "enterprise" fundraising role. At the other extreme, a study of a medical support "organization" in the UK, and a vegan campaign group in Poland demonstrated that they exist mainly to share knowledge, with "enterprise", in a financial sense, only present to support their main function. In between, and also studied, but not reported in depth here, were 6 other CoPs fundraising and/or campaigning, and thus sharing and disseminating knowledge, for their cause. The differences between these CoPs are discussed and underpinned by a review of relevant literature. What these disparate groups have in common is that they are all comprised of motivated people, voluntarily operating in communities of practice, and involved in knowledge transfer processes.

The following hypothesis is formulated: that communities of practice (CoPs) exist in social organizations or enterprises, and that the knowledge transfer techniques occurring in them could be identified and evaluated, using qualitative analysis techniques. Furthermore, that these techniques could reveal the motivation to form, join, participate in, and lead these groups.

The aim of the study was to probe and evaluate these processes qualitatively, using IPA techniques on CoPs operating with widely differing technical purposes, and in 2 different cultures. Altruistic and other forms of motivation, situated learning and other forms of knowledge management and transfer were investigated via qualitative interviews with CoP members.

\section{THEORY DEVELOPMENT}

\subsection{Knowledge management and transfer}

Contemporary management of enterprises and organizations is based in part on the acquisition of knowledge, and its use in current and strategic operations. The knowledge becomes a key organizational resource, but formal departments and operational groups within the organization often seem not to be able to successfully create, spread and use knowledge. Traditional approaches to knowledge management try to capture existing knowledge in formal systems, procedures and databases ${ }^{3}$.

Tacit knowledge is hard to codify and transfer without personal interactions between the knowledge source and receiver ${ }^{4}$. However, knowledge, and especially its tacit

\footnotetext{
${ }^{3}$ J. Mu, G. Peng, E. Love, Inter-firm networks, social capital, and knowledge flow, "Journal of Knowledge Management" 2008, No 12, 86-100.

${ }^{4}$ R. Teigland, M. Wasko, Knowledge transfer in MNCs: Examining how intrinsic motivations and knowledge sourcing impact individual centrality and performance, "Journal of International Management" 2009, 15, 15-31.
} 
dimension, is embedded in people and must be transformed into explicit organizational knowledge - this is the base of knowledge management ${ }^{5}$.

Knowledge management, information systems and the role of CoPs and other organizational groups in this field have been the subject of much research ${ }^{6}$. Simply, people believe that increasing awareness of the importance of embedded organizational knowledge has led to the development of a variety of information systems, that attempt to manage this knowledge ${ }^{7}$. These processes require support from the less formal groups in the organisation, including particularly, communities of practice ${ }^{8}$.

2.2 The community of practice as a place of knowledge creation and transfer

A Community of Practice has been identified as being a group where soft or subtle knowledge is created, shared and sustained ${ }^{9}$. The concept of a CoP was introduced by Lave and Wenger, who used it to explore situated learning ${ }^{10}$. The concept here is used as a potential initial theoretical framework from which to explore the chosen phenomenon, of situated learning in social organizations and enterprises. Wenger et al. (2002) state that a CoP contains a group of individuals, often working informally, sharing knowledge and motivated by common interests, concerns or practices. They define practice as organised activities of individuals and groups informed by a particular organizational or group context ${ }^{11}$.

Ribeiroa et.al propose to define the CoP in terms of three aspects ${ }^{12}$. Firstly, the nature of phenomena. This is a special platform of activity, organized from the bottom up and accumulating knowledge resources. It is a joint activity that evolves "and continually renegotiated by its members". Secondly, the course of action. People join the CoP, on the basis of shared interests and experiences. They are involved in convergent themed activities and co-create a single social entity. The members form a set of resources and services over time. These are explicit effects (e.g. documents stored) and tacit (original organizational culture, patterns of behaviour, etc.). Also Ruuska and Vartiainen developed some characteristics, which refer to the results of the CoP at different organizational levels ${ }^{13}$. Communities usually set their ideas and purposes around knowledge needs. The main means of activity are shared actions, discussions and an exchange of experiences,

\footnotetext{
${ }^{5}$ A. C. Inkpen, A. Dinur, Knowledge management processes and international joint ventures, "Organization Science" 1998, 9(4), 454-468.

${ }^{6}$ I.a.: J. Windsperger, N. Gorovaia, Knowledge attributes and the choice of knowledge transfer mechanism in networks: the case of franchising, "Journal of Management \& Governance" 2011, 15, 617-640; R. Teigland, M. Wasko, op. cit., 15-31.

7 R. Ribeiro, Ch. Kimble, P. Cairns, Quantum phenomena in Communities of Practice, "International Journal of Information Management" 2010, 30, 21-27.

${ }^{8} \mathrm{~S}$. Pavlin, Community of practice in a small research institute, "Journal of Knowledge Management" 2006, 10 (4), 136-144.

${ }^{9}$ P.J. Hildreth, C. Kimble, The duality of knowledge, "Information Research 2002", 8(1), paper no. 142, Available at: http://InformationR.net/ir/8-1/paper142.html, (12.04.2016)

${ }^{10}$ J. Lave, E. Wenger, Situated Learning. Legitimate Peripheral Participation, Cambridge University Press, 1991.

${ }^{11}$ E. Wenger, R. McDermott, W.M. Snyder, Cultivating Communities of Practice, Harvard Business Press 2002.

${ }^{12}$ R. Ribeiro, Ch. Kimble, P. Cairns, op. cit., 21-27.

${ }^{13}$ I. Ruuska, M. Vartiainen, Characteristics of knowledge sharing communities in project organizations, "International Journal of Project Management" 2005, 23, 374-379.
} 
mutual learning and talks about difficult cases. A CoP needs some co-ordination. Leadership in the CoP may be formalized and divided, thence focused on work in subgroups. The co-ordinators facilitate and help the community to focus on activity, maintain relationships, develop practice, and promote discussions. The effects of activity can relate to three levels: organization, subgroups and individual levels. However, the results of these actions may be difficult to evaluate, because they may occur outside the community.

\subsection{Social enterprises}

Stakeholders in society today, including scholars, governments, media, and nongovernmental organizations (NGO's) are increasingly recognizing the importance of social enterprise and the individuals who undertake it, here described as social entrepreneurs. Pearce uses a definition of enterprise in the social economy that includes all economic entities that have a social purpose, thus are not primarily (if at all) focused on the creation and distribution of capital. They are often democratic, rational and usually contain a common type of management structure ${ }^{14}$. Thus social entrepreneurs, both in the form of individuals and of organised groups, with their often novel approach to today's world problems, place high value on the creation of both social and (sometimes) economic values.

A social enterprise is an organization that trades, not for private gain, but to generate positive social and environmental externalities ${ }^{15}$. Doherty et al. explore "the concept of SE as an organizational form that has emerged as the boundaries between the private, public and non-profit sectors have become blurred and more fluid" ${ }^{16}$.They treat social enterprises as hybrid organizations, which "span institutional boundaries" between the private, public and non-profit sectors ${ }^{17}$. The authors needed some limits, so chose to define social enterprise as individuals that form or join groups, who then labour to develop specific products and/or services, then give them away, or recover cost only.

\section{METHODOLOGY}

10 groups were selected from a much larger pool, via "snowball" processes in the UK and Poland. Northern England was used for the study of 6 groups, and Southern Poland for 4. They were studied between 2009 and 2016. All these groups were purposively selected from options available, to be local and independent - not controlled by a central charity or "head office". This ensured that they made their own decisions on how to operate, train and share knowledge. Some of the groups had umbrella organizations, but all worked independently, and devised their own processes. This was a pre-requisite of inclusion. Thus, all the enterprises and organizations were purposively chosen as being self-starting communities of practices, operating with specific social agenda's.

Qualitative analysis techniques were an obvious choice. This was researched in depth prior to the primary research. Semi-structured interviews were held with 31 individuals representing a mixture of locally operating social enterprises and organizations. The

\footnotetext{
${ }^{14}$ J. Pearce, Social Enterprise in Anytown, Calouste Gunbelkian Foundation, London 2003.

${ }^{15}$ Santos, F.M. (2012). A positive theory of social entrepreneurship.) Journal of Business Ethics, 111 , pp. 335-351.

${ }^{16}$ B. Doherty, H. Haugh, F. Lyon, Social Enterprises as Hybrid Organizations: A Review and Research Agenda, International Journal of Management Reviews, Vol. 16, p. 417-436.

${ }^{17}$ Ibidem.
} 
interviews were recorded as audio files and the interviewer also made extensive notes. To preserve anonymity each group was only reported as "M", "L" etc. The interviews were transcribed and an Interpretative Phenomenological Analysis methodology was then used. "Meaning units" were identified using criteria from Langridge. He states: "When trying to determine the units of meaning, the analyst should be limited by two horizons to the meaning that they construe (...) to discern meaning units, it is necessary to do this with an eye for where the experience relates to issues appropriate. (...) So one might notice motions $(\ldots)$ but not organization dynamics, unless they impact directly $(\ldots)^{18}$.

Notes were made, firstly "Initial Thoughts", or unstructured first impressions. The next stage involves assessing the meaning units for their psychological significance. What is important at this stage is the move from idiosyncratic detail to more general meaning ${ }^{19}$. The largest transcript analysis created over 400 "meaning units", the smallest around 50.

The emerging themes were labeled using features described by Collins, Brown and Newman including observation, coaching, scaffolding, modeling, fading, and reflection ${ }^{20}$. Also, the works of Fairclough, distinguishes four "research objects": emergence, hegemony, recontextualisation and operationalisation ${ }^{21}$, and relates them to strategic critique. The authors believe that these are forms of situated learning and used them as identifiers. These were then grouped as "emergent themes" or "higher level ideas", in the right hand row. This again follows the methodology described by Langridge. He describes 4 stages, which the Interpretative Phenomenological Analysis (IPA) process used here, follows closely. In stage 2 he states: "Emerging themes are noted in the right hand margin (see table for examples). Initial notes are transformed into more meaningful statements(...) These comments should reflect broader, perhaps more theoretically significant concerns" ${ }^{22}$. The Figure below outlines the process used.

These were then grouped as "emergent themes" or "higher level ideas", in the right hand row. This again follows the methodology described by Langridge ${ }^{23}$. He describes 4 stages, which the Interpretative Phenomenological Analysis (IPA) process used here, follows closely. In stage 2 he states: "Emerging themes are noted in the right hand margin (see table for examples). Initial notes are transformed into more meaningful statements $(. .$.$) These comments should reflect broader, perhaps more theoretically$ significant concerns" 24 .

\footnotetext{
${ }^{18}$ D. Langridge, Phenomenological Psychology. Theory, Research and Method, Pearson. Prentice Hall 2007, p. 89.

${ }^{19}$ Ibidem

${ }^{20}$ A. Collins, J.S. Brown, S.E. Newman, Cognitive apprenticeship: Teaching the crafts of reading, writing, and mathematics. In L. B. Resnick (Ed.) Knowing, learning, and instruction: Essays in honor of Robert Glase, Hillsdale, NJ: Lawrence Erlbaum Associates. 1989, 453-494.

${ }^{21}$ N. Fairclough, Analyzing Discourse and Text: Textual Analysis for Social Research, Routledge, London 2003; N. Fairclough, Critical discourse analysis, "Marges Linguistiques" 2005, 9, 76-94; N. Fairclough, R. Jessop, A. Sayer, Critical realism and semiosis. In: J. Joseph, J. Roberts (eds.) Realism discourse and Deconstruction, Routledge, London 2004.

${ }^{22}$ D. Langridge, op. cit., p. 110-112.

${ }^{23}$ Ibidem

${ }^{24}$ D. Langridge, op. cit.,p. 110.
} 


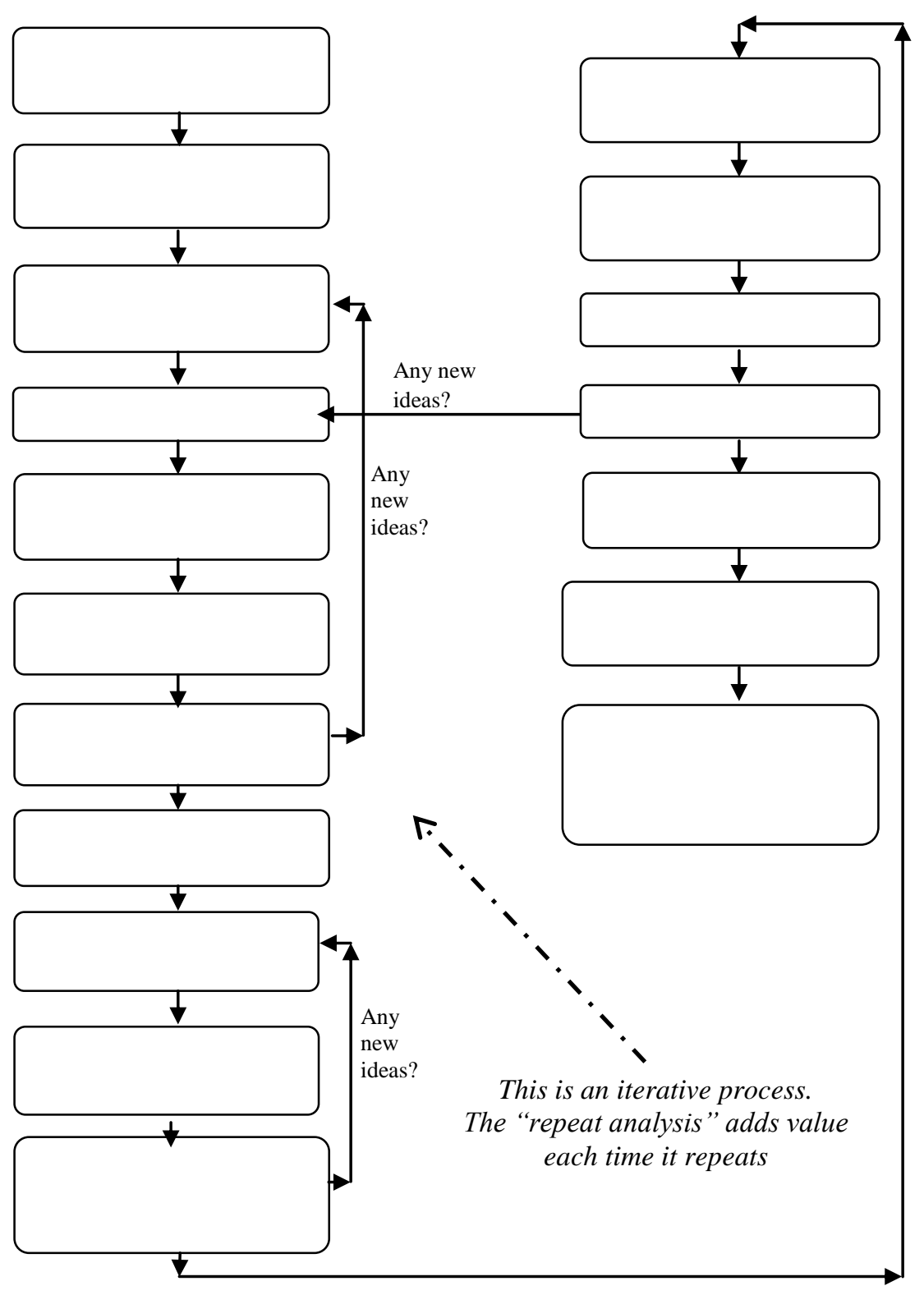

Fig. 1. The IPA process and subsequent analyses

Source: Authors' study

In the authors work, these comments often take the form of "knowledge transfer, community of practice formation, situated learning, emergence, operationalization etc". These emergent themes are mostly labels taken from the literature reported here. Finally, 
a textual summary was made below the IPA table. This completed the actual IPA for each interview.

This process reduced over 20 hours of interviews, and many pages of transcription, to around 400 pages of transcript, analysis and summation. This was then further mined, with constant referral back to its original sources, and analysed further using other tools, to create summary conclusions for each group. These conclusions typically comprised between 5-15 pages, giving well over 80 pages of IPA output from the 31 transcripts. Finally, they were compared between groups, countries and technical purposes.

The volume of work required has occupied over 5 years, and each interview transcript was undertaken separately, where possible in different weeks, months or years to minimise "habituation". One consequence of this is some variability of description, but this is largely edited out. This detailed study of 31 people's attitudes, is much more than is usual for IPA studies.

In this brief paper, only the surface can be reported, however a book is with publishers and will describe and analyse all the groups in depth. For this paper, 4 groups have been selected to illustrate the process - in some depth. Poland and the UK each supplied 2, and represented enterprises and organizations in each country. This is sufficient to demonstrate the process and its outcomes. The chosen groups are a medical support organization in the UK "L", a vegan campaign group in Poland, "V", a fundraising motorcycling group in Poland " $\mathrm{M}$ " and the previously mentioned fundraising group for the Yorkshire Air Ambulance "AA".

The interviews were all conducted in the interviewee's native language, by the author whose native language was the same. The transcriptions and subsequent IPA were done by the same individual, in their native tongue. To ensure academic rigour, a clear demarcation was made between text sources. Thus, there were tables of analysis in English, and in Polish. The processes for identification of "initial thoughts" and "emergent themes" were discussed and agreed in each case. At this point, a translation process was required for the Polish analyses, to draw out the "meaning units", "initial thoughts" and "emergent themes" in English. This created an English summary text with translated source material.

\section{THE FOUR ANALYZED COMMUNITIES OF PRACTISE}

This section briefly details the technical purpose driving each of the 4 CoPs selected for this paper. 2 are from the UK, 2 Poland. One from each country is an organization, the other an enterprise.

The L (UK) organization formed to identify and share information between sufferers and relatives of those with a life threatening disease. When the group formed (1980s), the disease was not well known in the medical community, and sufferers reported many misdiagnoses in earlier years. They formed the group to share experiences and their knowledge with the wider community and the medical profession. This meets the need to study motivation and its knowledge transfer processes in a community of practice. From the transcripts, meaning units included: "The group was specifically formed because the disease was relatively unknown and still is..."; "It was formed ...to give the chance for sufferers to share their personal experiences... and to discuss medicines and medical treatment...."

These study outcomes demonstrate that this CoP, and the others selected, is real and meets all the desired criteria. It formed with a technical purpose to help disease sufferers 
and relatives. A quote illustrates this (and is a "meaning unit"): "Doctors have no knowledge of it, no-one else has any knowledge..." (talking about the 1990's); “(...) being fobbed off by medical people that she went to see."

The CoP has changed over the last 30 years, mainly because of increased awareness, and Internet forums, but there is evidence of knowledge transfer, both inwards and outwards, of situated learning, and the motivation for this. At the beginning there was a desperate need for knowledge.

The V organization (Poland) was formed in 2010 to work for animals and draw consumers attention to their plight. The members are vegans, who actively promote public perception of animals rights. The main purposes of their activities are: to educate adults and children to respect the rights of animals (especially livestock animals), to promote a vegan diet and a consciousness about meat consumption. Their main activities include street happenings, film screenings, and workshops for children and young adults. All these seek to stimulate these younger audiences to gain respect for animals, and encourage them to try vegan food. The group is an organization, as its priority is campaigning and knowledge transfer. Fundraising is secondary. Meaning units include: "The main motivation from the very beginning, the main goal really... was to educate, inform consumers about how they can affect the fate of animals."; "There are different motivations that led us to this, to take action to start actively doing something for animals."

The M CoP (Poland) is an enterprise formed in 2007 to benefit an orphanage. They are mostly motorcyclists, who actively promote their lifestyle. They actively fundraise, to buy gifts for children and items needed to help the people leaving the orphanage. The founders of the group had no previous experiences in this area. However their knowledge of similar organizations in the region helped, and the process of formalization was supported by another motorcyclists organization. Meaning units include: "I saw these children, I saw their smiles, some err... crying and it affected me so, it stated that, if I can help someone, why not?"; "Motorcycles unite us and it is generally recognized that in this environment there is no such thing that you have to motivate someone to do something."

Leadership shines through the transcripts (translated by the authors): "I would have done a lot for her... Behind her you go in the darkness! The leader made the call: 'I need help - I need someone'."; "Since we have created our own association and now we have already 6 years of experience - it's just some things were already learned."; "They are people, who I can count on... I have to determine the direction."

The Yorkshire Air Ambulance support group (UK) is independent, not part of a larger body, and is run only as a social enterprise. The interviewee gave specific permission to use the name. A quote from their website evidences this: "Like many people, I first became aware of the charitable status of the UK Air Ambulance services when they had a significant impact on my own life" 25 . An example meaning unit: "I can see where my efforts are making a difference. Because you see the yellow helicopter flying in and out of Leeds General Infirmary and other hospitals... And, because of what I do I get to meet people, that's picked up. And I have met people whose lives have been saved by... the efforts that I put in, and... you just can't buy that, can you?"

\footnotetext{
${ }^{25} \mathrm{http}$ //www.yorkshireairambulance.org.uk/info/volunteers, (1.4.2016).
} 


\section{DISCUSSION OF RESULTS}

The results demonstrate that altruistic motivation, situated learning, knowledge transfer and management were clearly apparent in every CoP studied. Knowledge transfer was always evident, and a transition from Legitimate Peripheral Participation (LPP) to mature leadership or position was often seen. This was especially evident for management skills, and their operationalization in these organizations. However, and totally unexpected by the authors, was a clear separation between the CoPs operating as enterprises and those operating as organizations. When selected for study, the authors did not expect to see this division. This paper only reports $4 \mathrm{CoPs}$ in depth, but exemplifies all.

The commonest "emergent theme" in all groups was their rationale, or motivation to achieve their technical purpose. This was evidenced by a desire to transfer knowledge outwards, to others in the CoP organization. A second priority was to gain situated learning - knowledge transferred within the $\mathrm{CoP}$ itself, and then motivation to help others.

The $\mathrm{L}$ and $\mathrm{V}$ organizations demonstrate this particularly well. In the $\mathrm{V}$ group: : "I worked previously for Foundation xxx, ...another organisation, in which I really gained a lot of experience..."; "On the basis of what was already in our head, that we knew how to more or less organize events, happenings, how to write press releases, invite the media (...)"; "I am simply saying: we read and we train ourselves". There is clear evidence of knowledge transfer, both inwards and outwards, of situated learning and motivation. There is evidence that it is an organisation "in progress", growing and forming, undertaking organisational modelling, likewise "building scaffolding". The CoP has a clear leader, who is well prepared, and has a wealth of experience. The organization members utilize external sources of knowledge, then transfer it into the group (internalization) and share it with other members (socialization). After that the knowledge is usually combined with personal experiences and other tacit learning, and then externalized explicitly.

The focus of the $\mathrm{M}$ enterprise is clearly fundraising, with a secondary rationale of awareness raising: Motivation is clear: "This year we collected over 20,000 PLN". There is evidence of situated learning occurring in this community of practice, usually combined with personal experiences and other tacit learning, and then this is externalized. Tacit knowledge becomes explicit. Legitimate Peripheral Participation (LPP) becomes maturity, and the cycle continues. Situated learning includes aspects of motivation and hegemony. Less often seen are aspects of recontextualisation, operationalisation, fading and emergence. This is a function of the "loose but strategically controlled" group focus.

The Air Ambulance enterprise interview also repeatedly stressed the need for fundraising, clearly the key role of the group. A meaning unit: "We need to raise 10,000 pounds a day". Their motivation was a key underpinning theme. Altruistic reward was often noted ,(going to....) it was grand“. Situated learning and knowledge transfer were less important but evident. The interviewee's situated learning or background from his earlier life was purposively used for, but possibly not expressly transferred to the CoP. $\mathrm{He}$ stated though that he experienced situated learning himself, discovering how to analyse, identify and propose solutions to the problems he found. In this time he moved from his initial status of Legitimate Peripheral Participation (LPP), as a newcomer, on the periphery, to mature membership of the CoP.

In summary, the "technical purpose" of each CoP defined whether it functioned as an organization or enterprise. Motivation was almost always altruistic and a core 
prerequisite. So, the medical support "L" organization in the UK evolved and quickly became a knowledge platform. Situated learning was about managing the illness and its consequences. Knowledge of lifestyle choices, diagnosis and drug prescription consequences were the key items of knowledge. Making them explicit, transferring them to others and the processes required for this, made up the CoP's function. Raising awareness inside and outside the $\mathrm{CoP}$ was a core skill, and this clearly included campaigning. The $\mathrm{V}$ organization in Poland was very similar.

In contrast, the Air Ambulance in the UK, and the "M" orphanage fundraising enterprises in Poland have very different technical backgrounds, but both are clearly committed to raising funds for their cause. Knowledge and its transfer do not feature as heavily, possibly because the requisite methods are well established. However, situated learning features heavily, with the ability to use marketing skills, public relations and networking techniques from their personal backgrounds, in this different situation. One key part of knowledge management is the legality and bureaucratic requirements, not a stressed feature of $\mathrm{M}$ or $\mathrm{V}$. Motivation is again clearly the centre of their rationale for existence.

Common features also include the observation that external training and education was never utilized directly by these CoP's, although its existence in a previous role was often quoted. Thus, the CoP's all benefited from prior learning, making tacit knowledge explicit, and operationalizing it in the new CoP led context. Situated learning however, was evident in every case studied, with the CoP members learning about the technical problems their group faced, in the situation or context of its operation, and applying their tacit knowledge (or in some cases personally undertaken research) to their situation. Often, this was then made explicit to the CoP, via presentations, newsletters, informal conferences and other knowledge transfer techniques. Facebook is often cited as a core tool, and this is to be studied separately.

\section{CONCLUSIONS}

There are many similarities between the Polish and UK organizations, despite clear cultural differences. The country of operation, and the "technical" purposes of the organizations, although very different, did not greatly influence the mechanisms of knowledge management or transfer reported. The most striking emergent finding, not expected by the authors when the study started, was the clear separation of enterprises and organizations.

Enterprises exist to raise funds, sometimes with an important but secondary campaigning role. Underpinning their ability to operate, is knowledge and its transference. How to raise funds effectively, the legal hoops to jump through, and requisite marketing techniques, are key areas for enterprises.

Organizations are different. Money is almost irrelevant, as is legal structure in most cases. Knowledge is the core asset. Finding out how to manage the problem, spreading it within the CoP membership, and campaigning externally to raise awareness are the core skills in organizations.

However, motivation and knowledge transfer underpin every case studied. Motivation is almost always altruistic, although many reported personal gain from their situated learning experiences. Tacit knowledge became explicit, situated learning became operationalized and the CoP, with its "customers" - the people for whom it was created, 
benefit by its transfer. This process is common, whether applied to organization or enterprise.

\section{REFERENCES}

[1] Collins A., Brown J.S., Newman S.E., Cognitive apprenticeship: Teaching the crafts of reading, writing, and mathematics. In L. B. Resnick (Ed.) Knowing, learning, and instruction: Essays in honor of Robert Glase, Hillsdale, NJ: Lawrence Erlbaum Associates. 1989, 453-494.

[2] Doherty B., Haugh H., Lyon F., Social Enterprises as Hybrid Organizations: A Review and Research Agenda, "International Journal of Management Reviews" 2014, 16, 417-436.

[3] Fairclough N., Analyzing Discourse and Text: Textual Analysis for Social Research, Routledge, London 2003.

[4] Fairclough N., Critical discourse analysis, "Marges Linguistiques" 2005, 9, 76-94.

[5] Fairclough N., Jessop R., Sayer A., Critical realism and semiosis. In: J. Joseph, J. Roberts (eds.) Realism discourse and Deconstruction, Routledge, London 2004.

[6] Hildreth P.J., Kimble Ch., The duality of knowledge, "Information Research 2002", 8(1), paper no. 142, Available at: http://InformationR.net/ir/8-1/paper142.html, Accessed: 12.04.16.

[7] http://www.yorkshireairambulance.org.uk/info/volunteers, (1.4.2016).

[8] Inkpen A.C., Dinur A., Knowledge management processes and international joint ventures, "Organization Science” 1998, 9(4), 454-468.

[9] Langridge D., Phenomenological Psychology. Theory, Research and Method, Pearson, Prentice Hall 2007.

[10] Lave J., Wenger E., Situated Learning. Legitimate Peripheral Participation, Cambridge University Press, 1991.

[11] $\mathrm{Mu}$ J., Peng G., Love E., Inter-firm networks, social capital, and knowledge flow, "Journal of Knowledge Management" 2008, No 12, 86100.

[12] Pavlin S., Community of practice in a small research institute, "Journal of Knowledge Management" 2006, 10 (4), 136-144.

[13] Pearce J., Social Enterprise in Anytown, Calouste Gunbelkian Foundation, London 2003.

[14] Ribeiro R., Kimble Ch., Cairns P., Quantum phenomena in Communities of Practice, "International Journal of Information Management" 2010, 30, 21-27.

[15] Ruuska I., Vartiainen M., Characteristics of knowledge sharing communities in project organizations, "International Journal of Project Management" 2005, 23, 374-379.

[16] Santos, F.M., A positive theory of social entrepreneurship, "Journal of Business Ethics" 2012, 111, 335-351.

[17] Teigland R., Wasko M., Knowledge transfer in MNCs: Examining how intrinsic motivations and knowledge sourcing impact individual centrality 
and performance, "Journal of International Management" 2009, 15, 1531.

[18] Wenger E., McDermott R., Snyder W.M., Cultivating Communities of Practice, Harvard Business Press, Boston Massachusetts 2002.

[19] Windsperger J., Gorovaia N., Knowledge attributes and the choice of knowledge transfer mechanism in networks: the case of franchising, "Journal of Management \& Governance" 2011, 15, 617-640.

\section{ZARZĄDZANIE WIEDZĄ W ORGANIZACJACH SPOŁECZNYCH W WIELKIEJ BRYTANII I POLSCE}

Artykuł przedstawia wyniki badań obszernego studium małych organizacji społecznych. W badaniu wzięło udział 10 organizacji z Anglii i Polski. Zostały przebadane 31 osoby, reprezentujące mieszankę lokalnych przedsiębiorstw społecznych i organizacji. Transkrypcje wywiadów przeanalizowano przy użyciu interpretatywnej analizy fenomenologicznej. Autorzy zbadali poszczególne formy motywacji, aspekty uczenia sytuacyjnego oraz inne formy zarządzania wiedzą i jej transferu.

W niniejszym artykule założono hipotezę, że jakościowe metody badań mogą ujawnić motywację do tworzenia, uczestniczenia i prowadzenia organizacji społecznych oraz ocenić stosowane techniki transferu wiedzy. Celem badań było zbadanie i ocena tych procesów wśród praktyków działających w szerokim przekroju organizacji i w różnych kulturach - z wykorzystaniem interpretatywnej analizy fenomenologicznej

Wyniki pokazują, że uczenie sytuacyjne i zarządzanie wiedzą były w tych organizacjach wyraźnie widoczne. Transfer wiedzy był oczywisty, a także często postrzegano przechodzenie członków organizacji $\mathrm{z}$ początkowego stadium uczestnictwa do przywództwa. Było to szczególnie widoczne w przypadku umiejętności menedżerskich i ich operacjonalizacji w tych organizacjach.

Istnieje wiele podobieństw między organizacjami polskimi i brytyjskimi, mimo wyraźnych różnic kulturowych. Kraj funkcjonowania oraz cele „techniczne” organizacji, choć bardzo różne, wpływały nieznacznie na mechanizmy zarządzania wiedzą i jej transferu.

Słowa kluczowe: zarządzanie, wiedza, organizacje społeczne

DOI:10.7862/rz.2016.hss.79

Przesłano do redakcji: wrzesień 2016

Przyjęto do druku: grudzień 2016 